\title{
GUANYLINS - AGENTS WITH NATRIURETIC EFFECT
}

\author{
Pavlina Solichova*, David Stejskal, Jitka Proskova
}

Department of Laboratory Medicine, Hospital Sternberk, Czech Republic
e-mail: solichova.pavlina@seznam.cz

Received: July 11, 2005; Accepted (with revisions): June 23, 2006

Key words: cGMP/G-C family/Guanylins/Proguanylin/Uroguanylin

Guanylins and uroguanylins are natriuretic peptides with different effects in many of tissues. In context with guanylins, the intestine-renal axis is presented. The overproduction of guanylin or uroguanylin leads to secondary diarrhea with stimulation of $\mathrm{Cl}^{-}$secretion. A diet high in salt lead especially to increased guanylin and uroguanylin secretion. Interesting applications with guanylins measurement could to be in hypertension diagnosis, monitoring of heart dysfunction treatment, intensive care etc.

\section{INTRODUCTION}

Guanylin is a peptide recently isolated from the intestine, whose effects are similar to bacterial heat stable enterotoxines. ${ }^{1,4}$

Guanylin, uroguanylin and bacterial heat stable enterotoxines form the family of agonists to cyclic guanosine monophosphate (cGMP).

Guanylin is produced by mature intestinal caliculus cells together with mucine and D cells found there as well. It is produced as a pro-hormone with low biological activity. ${ }^{1,11,12}$

Uroguanylin was found in the intestine and urine several years after the discovery of proguanylin. ${ }^{9}$

According to recent work it seems that guanylin and uroguanylin are present in a number of tissues, especially in the gastrointestinal tract, in the central nervous system, in reproductive tissue and the lymphatic system.

\section{GUANYLIN RECEPTORS}

The guanylin and uroguanylin receptors are a members of the protein family of the guanylat cyclase (GC-C family) and were detected in the proximal tubule of kidneys (activation of this receptor was proven by guanylin as well as by uroguanylin) and in the seminiferous tubule of testes.

Other locations where guanylin receptors have been detected were intestines, suprarenal medulla, uterus, fallopian tubes, aerial epithelial cell, olfactory organs, trachea, and the brain. It seems that guanylin may play a key role in the regulation of functions of a number of tissues (e.g. kidney or liver). ${ }^{3,10}$

\section{EFFECTS OF GUANYLIN AND UROGUANYLIN}

Uroguanylin and guanylin are peptides which influence the production of cGMP in enterocytes (and other tissues - see above) by activation of apical membrane, when the activation of guanylat cyclase takes place. Presumably these hormones play a role in the so-called "intestinalkidney axis", which directly influences the regulation of salt and water homeostasis.

Increase in intracellular cGMP by guanylin leads to stimulation of $\mathrm{Cl}^{-}$secretion, which causes increased intestinal secretion of fluids into the intestine. ${ }^{6}$

Overproduction of guanylin or uroguanylin leads probably to secondary diarrhea, which is typically found in certain bacterial colonization of gastrointestinal tract when the bacteria produce peptide analogs of these endogenous hormones. ${ }^{5}$

\section{INTESTINAL GUANYLIN}

Proguanylin, guanylin, preprouroguanylin and uroguanylin are found in the circulation. Intestinal guanylin is mostly produced on the luminal side epitheliums. The peptide is released as propeptide with 94 residues, which is afterwards processed into small, bioactive form (so called luminocrine secretion). Carbachol stimulates the release of proguanylin of intestinal mucus, but the increase of bioactive C-terminal derivate is found especially on the apical side. Probably uroguanylin as well as proguanylin basolateral release is the source of circulating proguanylin which is afterwards proteolyticaly split into an active peptide in end tissues. ${ }^{13}$

Regulation of the intestinal transport of salts and fluids is absolutely fundamental in relation to the bloodstream. It seems that control of this life essential activity is mediated by the effect of hormones, neurotransmitters, 
and locally acting factors. In this regulation the intestinal peptide guanylin probably plays the key controlling role.

\section{UROGUANYLIN}

Uroguanylin is a structurally similar protein which is found in the urine in larger amounts, has similar biological activity as guanylin, and is synthesized in the intestine as well. This peptide may play a role as a link between the intestine and kidneys (intestinal-kidney axis), which hormonally controls renal salt excretion.

Preprouroguanylin which contains active uroguanylin peptide in its C-central part has been described. mRNA of preprouroguanylin was found in small and large intestine, in the atria and ventricles of heart, but not in the kidneys, stomach or liver. It seems that this peptide is mainly produced by the intestines and heart which enable fluid volume regulation. Uroguanylin is probably a kind of intestinal natriuretic hormone. This was later verified in clinical studies as well, where increased natriuresis was proven in people after oral ingestion of salts (see below).

Above all, uroguanylin and guanylin together participate in the regulation of salt and water intestinal transport; thus their role in salt and water homeostasis is almost certain. ${ }^{5-8}$

\section{MEASUREMENT OF GUANYLIN AND UROGUANYLIN IN HUMANS}

The concentration of uroguanylin was measured in people (RIA), where it was proven that the excretion of uroguanylin into urine in people on high salt diet $(10 \mathrm{~g} /$ day) was ( $137.8 \pm 14.4 \mathrm{pmol} /$ day $)$ significantly higher than in people on low salt diet $(7 \mathrm{~g} /$ day, $95.1 \pm 16.3 \mathrm{pmol} /$ day, $\mathrm{p}<0.05)$. Significant positive correlations were confirmed between urinary excretion of uroguanylin and urine values of $\mathrm{Na}^{+}, \mathrm{Cl}^{-}, \mathrm{K}^{+}$or cGMP. The plasma uroguanylin correlated with serum creatinine $(\mathrm{r}=0.71, \mathrm{P}<0.001) .{ }^{10}$

A different study found that a diet high in salt leads especially to increased guanylin secretion ( 3 times), less uroguanylin secretion. Also the application of hyperosmolar manitole leads to a smaller, but still significant increase in guanylin secretion. The increased guanylin leads directly to an increase in water and salt secretion by the intestine. These studies confirm a previous hypothesis about the guanylin effect (and the members of the peptide family) on the regulation of salt and water metabolism. ${ }^{14}$

The guanylin concentration was also measured in people with renal insufficiency. The plasma guanylin concentration in normal people is approximately $31.2 \pm$ $3.0 \mathrm{fmol} / \mathrm{ml}$ (average $\pm \mathrm{SD}$ ); in individuals with chronic kidney failure and hemodialysis it is increased. ${ }^{2}$

\section{OUR EXPERIENCE WITH EXAMINATION OF PROGUANYLIN}

In the research on 167 healthy volunteers we proved that women have significantly higher values of proguanylin (medians 13.7 vs 11.6 ng/l). Proguanylin we measured with ELISA assay (Biovendor, Brno, Czech Republic). Simultaneously we tested 5 healthy probands with proguanylin sampling in every two hours within day and proved the existence of a diurnal rhythm of proguanylin with its maximum in the evening hours.

\section{POSSIBLE CLINICAL USE FOR ASSESSMENT OF GUANYLINS}

It seems that the assessment of these peptides could help the understanding of certain functions of the regulation of water and mineral metabolism and better knowledge of the treated patient compensation. ${ }^{15}$

\section{GUANYLINS AS POTENTIAL DRUGS FOR TREATING A VARIETY OF DISEASE}

Guanylins are hot candidates for the therapy of heart failure, which would be focused on their receptors e.g. in the intestine and kidneys. Further possibilities for their use (or their agonists) are irritable colon with constipation, salt-dependent hypertension, liver recovery, respiratory disease (e.g. asthma). ${ }^{15}$

\section{REFERENCES}

1. Garcia KC, de Sauvage FJ, Struble M et al. (1993) Processing and characterization of human guanylin in Escheriachia Coli. $\mathbf{J}$ BiolChem, 136:22397-22401.

2. Nakazato M, Yamaguchi H, Shiomi K et al. (1994) Identification of $10-\mathrm{kDa}$ proguanylin as a major guanylin molecule in human intestine and plasma and its increase in renal insufficiency. Biochem Biophys Res Commun, 205:1966-1975.

3. Schulz S, Chrisman TD, Garbers DL. (1992) Cloning and expression of guanylin. Its existence in various mammalian tissues. J Biol Chem, 267:16019-16021.

4. Currie MG, Fok KF, Kato J, Moore RJ, Hamra FK, Duffin KL, Smith CE. (1992) Guanylin: an endogenous activator of intestinal guanylate cyclase. Proc Natl Acad Sci U S A., 89:947-51

5. Forte LR, Currie MG. (1995) Guanylin: a peptide regulator of epithelial transport. FASEB J, 9:643-650.

6. Hamra FK, Fan X, Krause WJ, Freeman RH, Chin DT, Smith CE, Currie MG, Forte LR. (1996) Prouroguanylin and proguanylin: purification from colon, structure, and modulation of bioactivity by proteases. Endocrinology, 137:257-265.

7. Fan X, Hamra FK, Freeman RH, Eber SL, Krause WJ, Lim RW, Pace VM, Currie MG, Forte LR. (1996) Uroguanylin: cloning of preprouroguanylin cDNA, mRNA expression in the intestine and heart and isolation of uroguanylin and prouroguanylin from plasma. Biochem Biophys Res Commun, 219:457-462.

8. Forte LR, Fan X, Hamra FK (1996) Salt and water homeostasis: uroguanylin is a circulating peptide hormone with natriuretic aktivity. Am J Kidney Dis, 2:296-304. 
9. Perkins A, Goy MF, Li Z. (1997) Uroguanylin is expressed by enterochromaffin cells in the rat gastrointestinal tract. Gastroenterology, 113:1007-1014.

10. Kinoshita H, Fujimoto S, Nakazato M, Yokota N, Date Y, Yamaguchi H, Hisanaga S, Eto T. (1997) Urine and plasma levels of uroguanylin and its molecular forms in renal diseases. Kidney Int, 52:1028-1034.

11. Fan X, Wang Y, London RM, Eber SL, Krause WJ, Freeman RH, Forte LR. (1997) Signaling pathways for guanylin and uroguanylin in the digestive, renal, central nervous, reproductive, and lymphoid systems. Endocrinology, 138:4636-4648.
12. Ieda H, Naruse S, Furuya S, Ozaki T, Ando E, Nokihara K, Hori S, Kitagawa M, Hayakawa T. (1998) Coexistence of proguanylin (1-15) and somatostatin in the gastrointestinal tract. J Gastroenterol Hepatol, 13: 1225-1233.

13. Martin S, Adermann K, Forssmann WG, Kuhn M. (1999) Regulated, side-directed secretion of proguanylin from isolated rat colonic mucosa. Endocrinology, 140:5022-5029.

14. Kita T, Kitamura K, Sakata J, Eto T. (1999) Marked increase of guanylin secretion in response to salt loading in the rat small intestine Am J Physiol, 277:960-966.

15. Forte RF. (2004) Uroguanylin and guanylin peptides: pharmacology, and experimental therapeutics. Pharmacology \& Therapeutics, 104:137-162. 